\title{
IMPROVEMENT OF INDONESIAN TOURISM SECTORS TO COMPETE IN SOUTHEAST ASIA
}

Tourism is an activity that directly touches and engages the community, thus bringing various benefits to the local community and its surroundings. Even tourism is said to have an extraordinary breakthrough energy, which is able to make local people experience metamorphosis in various aspects such as environment, social value \& knowledge, job opportunities \& opportunities. In the last decade, Indonesia's tourism sector has continued to expand and diversify. Not surprisingly, the government hopes that the tourism sector can bring fresh air in the midst of Indonesia's increasingly slumping oil and gas (oil and gas) and non-oil and gas sectors.

Meanwhile, last year, the tourism sector was estimated to be able to contribute to foreign exchange of $\$ 17.6$ billion, an increase of $9.3 \%$ from $\$ 16.1$ billion in 2018 . This is due to the increasing number of foreign tourist arrivals (tourists). The number of foreign tourists to Indonesia nearly doubled in a decade to 15.8 million in 2018 from 6.2 million in 2008. The government needs extra hard work to ensure the contribution of the tourism sector and competitiveness in South East Asia, also to curb the decline in foreign exchange earnings amid the sluggish world economy. The contribution of the tourism sector internationally and nationally shows positive economic prospects. The role of the government in the form of regulations and policies in tourism development efforts in Indonesia's economic development plan, namely the 2015-2019 RPJMN, shows that the government is aware of the great benefits provided by the tourism sector.

The tourism sector plays an important role in the economy in Indonesia as a whole. Efforts to increase the consumption of foreign tourists have an impact on increasing national income that is greater than the impact of increasing consumption of domestic tourists. The achievement of tourism development targets is more directed at developing the agricultural workforce, agricultural households and the hotel sector.

William Hansicc said in 2019, ASEAN (Association of Southeast Asian nations) was able to attract 133.1 million tourists who want to visit the amazing island to highland attractions 
with warm weather, unique cuisine, and colorful culture, report Mindanao Times. The number of international visitors to the ASEAN region is expected to grow at a combined annual growth rate of $4.72 \%$ from 129.2 million in 2018 to 155.4 million in 2022, the word global, data and analytical company leading. In 2019, around 60,000,000 Chinese travelers visited the region. However, if the area adheres to the 2020 plan, it can help muffle the punch. The plan includes ASEAN sustainable efforts to increase awareness of ASEAN tourism and its brand through digital channels and partnerships; Applying a marketing campaign involving influencers from long-distance markets, and launching guarantees new promotion to promote Southeast Asia. The number of tourist visits in ASEAN countries in $2019: 1$. Thailand 39,797,406 39.80 million ; 2. Malaysia 20.1 million ; 3. Vietnam 18 million ; 4. Singapore 15.9 million ; 5. Indonesia 13.62 million; 6. Philippines 8 million ; 7. Cambodia 6.7 million ; 8. Myanmar 4.3 million ; 9. Laos 3.4 million ; 10. Brunei Darussalam - 213 thousand. (Hansicc, 2020)

The Indonesian government must develop a number of things to be able to compete with countries in Southeast Asia in the tourism sector, such as those from the OECD in Ahmad Zafrullah mentioning the aspects that must be improved in an effort to increase the competitiveness of Indonesian tourism in terms of tourist attraction. Culture and History, Market Bonds, Mixed Activities, Special Events, Entertainment and Superstructures. Supporting Factors \& Resources are important things to be developed, in this aspect, things that need to be improved are Infrastructure, Accessibility, Facilitating Resources, Hospitality, and Enterprise. (Tayibnapis \& Sundari, 2020)

Destination management, according to the OECD in Ahmad Zafrullah, is important to improve based on the aspects of Resources Stewardship, Marketing, Finance \& Venture Capital, Organization, Human Resource Development, Information / research, Service Quality, and Visitor Management. Then the last aspect that must be improved is the determinant of Qualification, in this aspect it consists of several things including Location, Interdependence, Safety / Security, Awareness / Image / Brand, and Cost / Value. (Tayibnapis \& Sundari, 2020)

Tayibnapis \& Sundari (2020) stated that Indonesia has many opportunities in tourism development, for example in one important aspect, namely the Mix of Activity Indonesia can develop sports tourism, fashion, music, cultural performances, souvenirs and culinary, which are associated with natural beauty. and history. Organizing international events, such as sports tours, ballet shows, painting exhibitions and musical performances. Tour packages are less integrated and packaging tends to be monotonous. In addition, Facilitating Resources can also 
be developed through Tourism facilities that tend not to change and there are no new sensations to attract tourists. Tourists are always looking for new, unique, fun, and relaxing places that are integrated in one area, or close to each other. Tourism does not only require branding, but also intensive promotion. (Tayibnapis \& Sundari, 2020)

Indonesia's tourism and creative industries can serve as the backbone of the Indonesian economy. The potential for tourism and the creative economy owned by Indonesia is very large and can also provide a big leap effect for the development of the Indonesian economy. Therefore, there are several things that must be done by the Indonesian Government, one of which is the need for cooperation between the Central and Regional Governments so that the tourism sector is able to make a positive contribution to regional development, employment, retribution, foreign exchange, and others while maintaining sustainability. nature and local culture. The development of tourism in Indonesia is not only in infrastructure, but also in the ecosystem in an effort to support tourist destinations, such as aspects of culture, creativity, and hospitality so that people around tourist destinations are just spectators. Thus, tourism development is expected to provide economic, environmental and community benefits in a true sense.

\section{Refrensi}

Hansicc, W. (2020, Februari 11). Revealed Tourist Arrival to ASEAN Countries 2019. Retrieved from SEASIA.co: https://seasia.co/2020/02/11/revealed-tourist-arrival-toasean-countries-2019

Tayibnapis, A. Z., \& Sundari, M. S. (2020, Januari - Maret). Boosting Indonesia's Tourism Sector to be Competitive. Internation al Journal of Management \& Busin ess Studies (IJMBS), 10(01). 